Удк 616-089-06-616.361/.364-001.1] - 084

DOI 10.11603/2414-4533.2017.3.8119

М. М. ГРЕСЬКО, М. Д. ГРЕСЬКО

ВДнЗ України “Буковинський державний медичний університет”, Чернівці

\title{
Нестандартні ситуації в хірургічній практиці як причина ятрогенних пошкодженнь жовчовивідних шляхів
}

\begin{abstract}
Мета роботи: узагальнити досвід використання лапароскопічних втручань у хворих з ургентною та плановою хірургічною патологією та запобігти ймовірним ускладненням.

Матеріали і методи. У роботі проведено ретроспективний аналіз результатів лапароскопічних втручань у 8245 хворих із жовчнокам'яною хворобою (хронічний холецистит - 4905 хворих; поліпоз жовчного міхура -33 хворі; гострий холецистит 3307 хворих).

Результати дослідження та їх обговорення. Пошкодження міхурової протоки або холедоха спостерігали у 19 хворих (синдром Міррізі мав місце у 13 хворих). Локалізація пошкоджень була наступною: загальна жовчна протока (I тип за H. Bismuth) - у 8 хворих, загальна печінкова протока (II тип за H. Bismuth) - у 6 хворих, загальна жовчна протока разом із біфуркацією (III тип за H. Bismuth) - y 4 хворих, загальна жовчна протока з пошкодженням конфлюенс (IV тип по H. Bismuth) - у одного хворого. У 5 хворих ятрогенні пошкодження жовчовивідних шляхів виявлено під час операції а у 14 хворих - у ранньому післяопераційному періоді. Все це вимагало вирішення надзвичайно важких та складних проблем у подальшому, оскільки послідовність використання діагностичних прийомів не однакова у всіх хворих. Слід зазначити, що задовільні результати спостерігали, коли ятрогенні пошкодження жовчовивідних шляхів були виявлені субопераційно.

У ситуації, коли неможливо провести стандартну лапароскопічну холецистектомію виникають різні ускладнення. Своєчасна конверсія - надзвичайно важливий момент попередження травмування жовчовивідних шляхів у технічно складних випадках, а відновлення відтоку жовчі може бути досягнуто тільки тоді, коли в операційну бригаду буде включений досвідчений фахівець, який володіє методиками відновних та реконструктивних операцій.
\end{abstract}

Ключові слова: жовчнокам’яна хвороба; ятрогенні пошкодження жовчовивідних шляхів; конверсія.

Постановка проблеми і аналіз останніх досліджень та публікацій. Сьогодні досить широко в практику впроваджена лапароскопічна холецистектомія (ЛХ), яка є основою хірургічного лікування хронічного калькульозного холециститу і стала “золотим” стандартом впродовж останніх 20 років [1, 2]. Однак запровадження лапароскопічної методики сприяло суттєвому (в 2-5 разів) збільшенню частоти пошкоджень магістральних жовчних проток у порівняно з відкритою технікою операції - до 0,3-2 \% [5, 6]. 3'явились описи характерних ознак, які вказують на так звані субопераційні ускладнення. Це такі терміни, як: “тяжкий жовчний міхур”, “операційний ризик ЛХЕ”, “нестандартні ситуації при ЛХЕ”, “підвищений операційний ризик при ЛХЕ”. Особливої значимості такі проблеми набувають під час операцій з приводу гострого холециститу $[4,5]$. Окрім того, у практиці хірурга зустрічається синдром Міррізі [7, 8, 9]. Саме це призвело до того, що з'явились оновлені Токійські клінічні рекомендації із лікування гострого холангіту та холециститу, які визнають світовими експертами в гепатопанкреатобіліарній хірургії і допомагають хірургу у виборі адекватної тактики лікування [10]. $€$ також публікації, які вказують на ситуації, коли неможливо провести стандартну лапароскопічну холецистектомію, і вони, як правило, призводять до субопераційних ускладненнь. Результати лікування таких пацієнтів не можна вважати задовільними через стабільно високий відсоток післяопераційних ускладнень і летальності [3, 7].

Мета роботи: узагальнити досвід використання лапароскопічних втручань у 8245 хворих 3 ургентною та плановою хірургічною патологією і встановити критерії, які спричиняють конверсію. Поліпшення результатів лікування хворих 3 ускладненнями, що вимагають багаторазових операційних утручань, шляхом оптимізації діагностичної та лікувальної програми.

Матеріали і методи. Під нашим наглядом знаходилось 8245 хворих на калькульозний холецистит віком від 16 до 84 роки (жінок - 6987 (84,74 \%), чоловіків - 1258 (13,26 \%)). Хронічний холецистит діагностовано у 4905 (59,45 \%) хворих; поліпоз жовчного міхура - 33(0,04 \%); гострий холецистит - у 3307 (40,51 \%), (гангренозний - у 576 хворих, флегмонозний - у 1114 хворих, катаральний - у 1650 хворих). Повторно лапароскопічні втручання виконані у 53 хворих 3 метою визначення наявності ускладнень в післяопераційному періоді. У 36 хворих лапароскопічні втручання використані для видалення кістозних утворень печінки та серпоподібної зв’язки. 
Результати дослідження та їх обговорення. Серед 4905 хворих на хронічний калькульозний холецистит у 1131 хворих були злуки жовчного міхура з іншими органами, тканинами. Це призвело до конверсії у 43 хворих. 33307 хворих на гострий калькульозний холецистит у 414 випадках зустрічався навколоміхуровий інфільтрат, що стало причиною конверсії у 56 хворих. Причини конверсії були: наявність короткої або широкої міхурової протоки - 17 хворих; пошкодження міхурової протоки або холедоха - 19 хворих (синдром Міррізі - у 13 хворих); інфільтрація тканин - 9 хворих; виникнення масивної кровотечі - 28 хворих (20 хворих із гострим та у 8 хворих -3 хронічним калькульозним холециститом); вклинений конкремент у міхуровій протоці - 12 хворих; підозра на наявність конкременту в залишеній куксі міхурової протоки - 9 хворих; наявність гематоми брижі поперечно-ободової кишки - 2 хворих; пошкодження товстої кишки внаслідок травми - одна хвора.

Особливий аналіз проведено серед 19 хворих з пошкодженням міхурової протоки або холедоха (синдром Міррізі спостерігали у 13 хворих). Локалізація пошкоджень була наступною: загальна жовчна протока (I тип за Н. Bismuth) - у 8 хворих, загальна печінкова протока (II тип за H. Bismuth) - у 6 хворих, загальна жовчна протока разом із біфуркацією (III тип за Н. Bismuth) - у 4 хворих, загальна жовчна протока з пошкодженням конфлюенс (IV тип по H. Bismuth) - у одного хворого.

У 5 хворих ятрогенні пошкодження жовчовивідних шляхів виявлено субопераційно. Основними критеріями, які вказували на пошкодження були:

1. Поява жовчі в операційному полі.

2. Потовщення прогнозованої міхурової протоки в процесі її виділення.

3. Виникнення по ходу операцій додаткових трубчатих структур.

\section{СПИСОК ЛІТЕРАТУРИ}

1. Мамонтов И. Н. Результаты лечения больных по поводу синдрома MIRIZZI / И. Н. Мамонтов // Клінічна хірургія. - 2016. - № 9. - С. 25-27.

2. Оценка результатов лапароскопической холецистэктомии при остром холецитите и его осложнениях / Р. В. Бондарев, А. И. Сопко, В. М. Иванцок, Р. Н. Козубович // Мат. ХХІІІ з'їзду хірургів України. - Київ. - 2015. - С. 54-55.

3. Лапароскопічна холецистектомія у лікуванні гострого калькульозного холециститу / М. О. Дудченко, М. І. Кравців, В. І. Ляховський, О. М. Люлька // Матеріали XXIII з'їздУ хірургівУкраїни. - Київ. - 2015. - С. 91-92.

4. Комбинированное анте- и ретроградное восстановление непрерывности общего печеночного протока после сочетанного ятрогенного повреждения / М. П. Королев, Л. Е. Фе-
4. Просякнення жовчі через прогнозовану куксу міхурової протоки.

5. Використання під час проведення операційного втручання більше кліпс, ніж звичайно.

6. Наявність хоча б однієї із вищеперерахованих ознак спонукає до негайної конверсії або до проведення інтраопераційної холангіографії.

У 14 хворих ятрогенні пошкодження жовчовивідних шляхів виявлено у ранньому післяопераційному періоді. Основними критеріями, які вказували на пошкодження, були:

1. Виникнення обтураційної жовтяниці.

2. Внутрішньочеревне або зовнішнє витікання жовчі.

3. Поєднання симптомів жовчної гіпертензії та витікання жовчі.

Все це призводило до вирішення надзвичайно тяжких та складних проблем в подальшому, оскільки послідовність використання діагностичних прийомів не однакова у всіх хворих. Слід зазначити, що задовільніші результати зустрічались тоді, коли ятрогенні пошкодження жовчовивідних шляхів були виявлені субопераційно.

Висновки. 1. Своєчасний перехід на конверсію - надзвичайно важливий момент попередження травмування жовчовивідних шляхів в технічно складних випадках. 2. Своєчасне відновлення відтоку жовчі може бути досягнуто тільки тоді, коли в операційну бригаду буде включений досвідчений фахівець, який володіє різноманітними методиками відновних та реконструктивних операцій. 3. Все це вимагає подальшого осмислення, аналізу і адекватної корекції з метою зменшення кількості негативних наслідків і більш широкого застосування цих щадних методик як в плановій, так і в ургентній хірургії.

дотов, Р. Г. Аванесян [и др.] // Вестник хирургии. - 2016. Т. 175, № 2. - С. 105-107.

5. Возможности лапароскопической коррекции желчекаменной коррекции при “трудном желчном пузыре” / Ф. Н. Махмадов, С. Р. Рафиков, Ф. Х. Кудритов // Эндоскопическая хирургия. - 2014. - № 20:1. - С. 259-260.

6. Ускладнення лапароскопічної холецистектомії та хірургічні методи їх корекції / О. С. Никоненко, М. Г. Головко, Є. І. Гайдаржі [та ін.] // Матеріали XXIII з'їзду хірургів України. - Київ. - 2015. - С. 146-147.

7. Пошкодження жовчних протоків при лапароскопічній холецистектомії / М. Ю. Ничитайло, А. В. Скумс, О. І. Литвин [та ін.] // Матеріали XXIII з’їзду хірургів України. - Київ. - 2015. - С. 153-154. 
8. Синдром Мирицци - причина ятрогенных повреждений гепатохоледоха / Г. Г. Алхадзе, А. Е. Котовский, Т. В. Унгуряну, Э. И. Гальперин // Consilium medicum Ukraina, гастроэнтерология. - 2009. - № 7. - С. 21-23.

9. An alternative surgical approach to a difficult case of Mirizzi syndrome: A case report and review of the literature
/ M. Safioleas, M. Stamatakos, C. Revenas [et al.] // World J. Gastroenterol. - 2006. - Vol. 12, No. 34. - P. 5579-5581.

10. TG13: Обновленные Токийкие клинические рекомендации по лечению острого холангита и холецистита / А. Ю. Усенко, В. Г. Ярешко, М. Е. Нечитайло, Ю. А. Михеев, С. А. Андреещев // Клінічна хірургія. - 2015. -№ 10. - С. 5-10.

\section{REFERENCES}

1. Mavontov, I.N. (2016). Rezultaty lecheniya bolnykh po povodu sindroma MIRIZZI [Results of treatment for MIRIZZI syndrome]. Klinichna khirurgiya - Clinical Surgery, 9, 25-27 [in Russian].

2. Bondarev, R.V., Sopko, A.I., Ivantsok, V.M., \& Kozubovych, R.N. (2015). Otsinka rezultativ laparoskopichnoi kholetsystektomii pry hostromu kholetsystyti ta yii uskladnenniakh [Evaluation of the results of laparoscopic cholecystectomy in acute cholecystitis and its complications]. Mat. XXIII zizdu khirurhiv Ukrainy - Proceedings of the XXIII Congress of Surgeons of Ukraine. Kyiv. (pp.54-55) [in Ukrainian].

3. Dudchenko, M.O., Kravtsev M.I., Liakhovskyi V.I., Liulka, O.M. (2015). Laparoskopichna kholetsystektomiia pry likuvanni hostroho kalkuloznoho kholetsystytu [Laparoscopic cholecystectomy in the treatment of acute calculous cholecystitis]. Mat. XXIII zizdu khirurhiv Ukrainy - Proceedings of the XXIII Congress of Surgeons of Ukraine. Kyiv. (pp.91-92) [in Ukrainian]. 4. Koroliev, M.P., Fedotov, L.Ye., Avanesyan, R.H., Fedotov, B.L., \& Lepekhin, H.M. (2016). Kombinovane anteretrohradne vidnovlennia bezperervnosti zahalnoho pechinkovoho protoku pislia poiednanoho yatrohennoho ushkodzhennia [Combined anti-retrograde restoration of the continuity of the common hepatic duct after combined iatrogenic damage]. Visnyk khirurhii - Journal of Surgery, 175 (2), 105-107 [in Russian].

5. Makhmadov, F.N., Rafikov, S.R., \& Kudritov, F.Kh. (2014). Mozhlyvosti laparoskopichnoi korektsii zhovchnokamernoi korektsii u "vazhkomu zhovchnomu mikhuri" [Possibilities of laparoscopic correction of bile-chamber correction in "difficult gall bladder"]. Endoskopichna khirurhiia - Endoscopic Surgery, 20 (1), 259-260 [in Russian].

6. Nykonenko, O.S., Holovko, M.H., Haidarzhi, Ye.I., Det- syk, D.A., Hrushka, V. A., Podluzhnyi, O.O., Havrylenko, T.S., \& Ishchuk, O.A. (2015). Uskladnennia laparoskopichnoi kholetsystektomii ta khirurhichni metody yikh korektsii [Complications of laparoscopic cholecystectomy and surgical methods of their correction]. Mat. XXIII zyizdu khirurhiv Ukrainy - Proceedings of the XXIII Congress of Surgeons of Ukraine. Kyiv. (pp. 146-147) [in Ukrainian].

7. Nychytailo, M.Yu., Skums, A.V., Lytvyn, O.I., Shkarban, V.P., Mikhalchevskyi, V.P., Skums, A.A., Shcherbina, S.I., \& Homan, A.V. (2015). Poshkodzhennia zhovchnykh protokiv pry laparoskopichnii kholetsystektomii [Damage to the bile duct in laparoscopic cholecystectomy]. Mat. XXIII zyizdu khirurhiv Ukrainy - Proceedings of the XXIII Congress of Surgeons of Ukraine. Kyiv. (pp. 146-147) [in Ukrainian].

8. Alkhadze, G.G., Kotovskyy, A.A., Unguryanu, T.V., \& Halperin, E.I. (2009). Sindrom MIRIZZI - prichina yatrogennykh povrezhdeniy gepatokholedokha [Miritstsi syndrome - the cause of iatrogenic lesions of hepatocholescope]. Consilium medicum Ukraina, gastroenterologiya - Consilium Medicum Ukraina, Gastroenterology, (7), 21-23 [in Ukrainian].

9. Safioleas, M., Stamatakos, M., \& Revenas, C. (2006). An alternative surgical approach to a difficult case of Mirizzi syndrome: A case report and review of the literature. World J. Gastroenterol., 12 (34), 5579-5581

10. Usenko, A.Yu., Yareshko, V.G., Nechitaylo, M.E., Mikheyev, Yu.A., Andreyeshchev, S.A. (2015). TG13: Obnovlenniye Tokyskie klinischeskie rekomendatsii po lecheniyu ostrogo kholangita i kholetsistita [TG13: The updated Tokyos clinical recommendations for treatment of an acute cholangitis and cholecystitis]. Klinichna khirurhiia - Clinical Surgery, (10), 5-10 [in Russian].

\section{M. HRESKO, M. D. HRESKO}

Bukovyna State Medical University

\section{NON-STANDARD SITUATIONS IN SURGICAL PRACTICE AS A GAUSE OF IATROGENIC INJURIES OF THE BILE TRACT}

The aim of the work: to generalize the experience of using laparoscopic interventions in patients with urgent and planned surgical pathology and to prevent probable complications.

Materials and Methods. In the work, a retrospective analysis of the results of laparoscopic interventions in 8245 patients with gallstone disease (chronic cholecystitis - 4905 patients, gallbladder polyposis - 33 patients, acute cholecystitis - 3307 patients) has been carried out.

Results and Discussion. Damage to the bubble duct or choledoch duct occurred in 19 patients (Mirrizi syndrome occurred in 13 patients). The localization of lesions was as follows: total bile duct (I type according to H. Bismuth) - in 8 patients, total liver duct (II type according to $\mathrm{H}$. Bismuth) - in 6 patients, total bile duct along with bifurcation (III type according to H. Bismuth ) - in 4 patients, the total bile duct with damage to the confluence (IV type according to H. Bismuth) - in 1 patient.

In 5 patients, iatrogenic damage to the biliary tract was detected during the operation, and in 14 patients - in the early postoperative period. All this led to the solution of extremely difficult and complex problems in the future, since the sequence of use of diagnostic 
techniques is not the same for all patients. It should be noted that more satisfactory results were then when iatrogenic damage to the biliary tract was detected sub-operatively.

In a situation where it is not possible to conduct a standard laparoscopic cholecystectomy there are various complications. Timely conversion is an extremely important moment in preventing injuries to the bile ducts in technically difficult cases, and recovery of bile outflow can be achieved only when an experienced specialist who has methods of restorative and reconstructive surgery is included in the operating team.

Key words: gallstone disease; iatrogenic injury of bile tract; conversion.

\section{М. М. ГРЕСЬКО, М. Д. ГРЕСЬКО}

ГВУз Украины “Буковинский государственный медицинский университет”, Черновцы

\section{НЕСТАНДАРТНЫЕ СИТУАЦИИ В ХИРУРГИЧЕСКОЙ ПРАКТИКЕ КАК ПРИЧИНА ЯТРОГЕННЫХ ПОВРЕЖДЕНИЙ ЖЕЛЧЕВЫВОДЯЩИХ ПУТЕЙ}

Цель работы: обобщить опыт использования лапароскопических вмешательств у больных с ургентной и плановой хирургической патологией и предотвратить вероятные осложнения.

Материалы и методы. В работе проведен ретроспективный анализ результатов лапароскопических вмешательств 8245 больных с желчекаменной болезнью (хронический холецистит - 4905 больных, полипоз желчного пузыря - 33 больных, острый холецистит - 3307 больных).

Результаты исследования и их обсуждение. Повреждения пузырного протока или холедоха имело место у 19 больных (синдром Мирризи имел место у 13 больных). Локализация повреждений была следующей: общий желчный проток (I тип по H. Bismuth) - у 8 больных, общий печеночный проток (II тип по H. Bismuth) - у 6 больных, общий желчный проток вместе с бифуркацией (III тип по H. Bismuth ) - у 4 больных, общий желчный проток с повреждением конфлюенса (IV тип по Н. Bismuth) - у одного больного.

У 5 больных ятрогенные повреждения желчевыводящих путей обнаружены во время операции, а у 14 больных - в раннем послеоперационном периоде. Все это приводило к решению чрезвычайно тяжелых и сложных проблем в дальнейшем, так как последовательность использования диагностических приемов не одинакова у всех больных. Следует отметить, что более удовлетворительные результаты были тогда, когда ятрогенные повреждения желчевыводящих путей были обнаружены субоперационно.

В ситуации, когда невозможно провести стандартную лапароскопическую холецистэктомию возникают различные осложнения. Своевременная конверсия - очень важный момент предупреждения ранения желчевыводящих путей в технически сложных случаях, а восстановление оттока желчи может быть достигнуто только тогда, когда в операционную бригаду будет включен опытный специалист, который владеет методиками восстановительных и реконструктивных операций.

Ключевые слова: желчекаменная болезнь; ятрогенные повреждения желчевыводящих путей; конверсия. 